\title{
Melatonin Ameliorates Cadmium-Induced Oxidative Damage and Morphological Changes in the Kidney of Rat
}

\author{
Gamal H. El-Sokkary ${ }^{*}, 1$, Allam A. Nafady ${ }^{2}$ and Elhammaly H. Shabash ${ }^{1}$ \\ ${ }^{1}$ Department of Zoology, Faculty of Science, ${ }^{2}$ Department of Pathology, Faculty of Veterinary Medicine, Assiut Univer- \\ sity, 71516 Assiut, Egypt
}

\begin{abstract}
The oxidative damage and morphological changes of kidneys of rats exposed to cadmium (5 mg Cd $/ \mathrm{kg}$ b.w) for 22 days and the protection using melatonin $(10 \mathrm{mg} / \mathrm{kg} \mathrm{b.w})$ against cadmium toxicity was studied. Malondialdehyde (MDA) concentration as a lipid peroxidation indicator, activity of the antioxidant enzyme superoxide dismutase (SOD) and the concentration of glutathione (GSH) were measured in kidney homogenates. The morphological changes were investigated using both light and electron microscopes. The exposure to $\mathrm{Cd}$ led to an increase in the MDA levels and a decrease in both the activity of SOD and the concentration of GSH versus controls. In contrast, melatonin administration restored the previous changes to nearly the normal levels. Morphologically, $\mathrm{Cd}$ led to different histopathological changes such as loss of the normal cortical tissue, atypical tubules with hamorrhage, cellular degeneration and necrosis, fat globules and slought cells (urine cast) in the tubular lumens. Again, melatonin administration counteracts all changes and the tissue appears more or less normal. The rate of recovery was faster when melatonin was administered for treatment after the exposure of animals to cadmium than if the animals left without any treatment. The results suggest that melatonin may be useful due to antioxidant properties in combating free radical-induced oxidative stress and tissue injury resulted from cadmium toxicity.
\end{abstract}

\section{INTRODUCTION}

Cadmium $(\mathrm{Cd})$ is an important industrial and environmental pollutant that currently ranks seventh on the ATSDR/EPA list of Hazardous Substances [1]. The kidney is the critical target organ for the general population as well as for occupationally exposed populations. Of the many reported toxic effects of Cd, some of the most serious involve the kidney. Wide ranges of tests with different sensitivities and levels of significance have been used among cadmiumexposed populations to assess cadmium nephrotoxicity [2]. Cadmium is known to accumulate in the human kidney for a relatively long time, from 20 to 30 years. Most studies have centered on the detection of early signs of kidney dysfunction in the occupational setting [3]. The highest load of cadmium is found in the renal cortex. Renal concentrations in second trimester fetuses and infants compared to autopsy studies in adults show renal cadmium concentration increases about 5,000 times from birth to adulthood [4]. Studies of cortex concentrations have found that women have significantly higher concentrations than men, in spite of a higher male smoking rate.

Impairment of renal tubular re-absorption function is a well established toxic effect of chronic exposure to low-level environmental cadmium $[5,6]$. Such impairment results in increased urine excretion of small molecular weight compounds that would be otherwise reabsorbed from the glomerular filtrate [7]. Chronic exposure to low-level Cd has also been associated with several other adverse health effects

*Address correspondence to this author at the Department of Zoology, Faculty of Science, Assiut University, 71516 Assiut, Egypt; Tel: ++/0882401724; Fax: ++/088/2342708; E-mail: Elsokkary2000@yahoo.com including osteoporosis, early onset of diabetic renal complications, end-stage renal failure, hypertension and increased cancer risk $[5,6,8,9]$. Individuals with signs of Cd-linked kidney toxicity had $40-100 \%$ increased mortality risk suggesting renal Cd toxicity is an early warning of complications, sub-clinical or clinical morbidity $[6,10]$.

The nephrotoxic effects of $\mathrm{Cd}$ are thought to occur when circulating $\mathrm{Cd}$ that is bound to metallothionein or other lowmolecular-weight materials in plasma is delivered to the epithelial cells of the proximal tubule, either at the apical or the basolateral cell surface, and taken up to such an extent that the renal cortical $\mathrm{Cd}$ concentration exceeds a critical threshold that results in cellular injury [11-13].

Oxidative stress is believed to participate in the early processes of cadmium $(\mathrm{Cd})$-induced proximal tubular kidney damage. Under normal conditions, antioxidant defense systems of the cell minimize the perturbations caused by reactive oxygen species (ROS). When ROS generation is increased to an extent that overcomes the antioxidant enzymes and molecules, it results in oxidative stress [14] causing damage to DNA, proteins or mitochondria, lipid peroxidation and apoptotic cell death $[15,16]$. Cd, which is not a redox active metal itself, can generate free radicals only indirectly. It is thought that $\mathrm{Cd}$ may replace redox active metals such as iron and copper, which in turn participate in free radical generation via Fenton reactions [17]. Cd-induced ROS formation may also be due to depletion of endogenous intracellular radical scavengers such as GSH, to which it binds with high affinity $[18,19]$.

The mechanisms of cadmium toxicity are not completely understood, but some of the cellular effects are known. Fifty to sixty percent of exposed populations have been shown to have chromosomal damage [20]. Some of the specific 
changes that lead to tissue damage and death in chronic exposure have been related to oxidative stress and thiol depletion [18]. Cellular damage results from cadmium binding to sulfhydryl groups in tissue, the production of lipid peroxides, and the depletion of glutathione.

The Protective effects of melatonin against metalinduced oxidative damage have been reported in studies done mostly in vitro [21-23] and in vivo [24-27]. Marshall et al. [28] reported that melatonin may afford protection against free radical-induced lipid peroxidation in vivo. Studies to test this possibility in vivo have been carried out and the findings uniformly suggest an antioxidative action of melatonin in lipid-rich environments.

Reports documenting the influence of melatonin on antioxidant enzyme activity were first published in the mid1990s [29, 30]. These papers described the amplification of GSH-Px activity in the brain of rat and in several tissues of chicks after exogenously administered melatonin (500 $\mu \mathrm{g} / \mathrm{kg})$. Thereafter, several groups showed that melatonin increases the activity of antioxidant enzymes in other tissues and models. Thus, Ozturk et al. [31] found increased SOD activity in rat liver after administration of $10 \mathrm{mg} / \mathrm{kg}$ of melatonin for 7 days, while Liu and $\mathrm{Ng}$ [32] reported enhancement of SOD activity in rat kidney, liver and brain after a single melatonin injection $(5 \mathrm{mg} / \mathrm{kg})$.

\section{MATERIALS AND METHODOLOGY}

\section{Animals}

75 adult male Sprague-Dawley rats weighting about 125 grams were used in the present work. They were purchased from Assiut University Joint Animal Breeding Unit. The animals were kept in a controlled light room with a photoperiod of 12 hours dark and 12 hours light (dark light cycle 12:12) with lights on from 6:00 to $18: 00 \mathrm{~h}$ at a temperature of $28 \pm 2{ }^{\circ} \mathrm{C}$. All animals were given free access to standard laboratory chow and tap water. Care and treatment of animals was approved and practices were performed according to approval of ethics regulation at the Assiut University.

\section{Chemicals}

Cadmium chloride $(\mathrm{Cd})$, melatonin, 2-thiobarbituric acid, 1,1,3,3-tetra-methoxypropane, dimethyl sulfoxide, sodium dodecyl sulfate, and epinephrine were purchased from Sigma Co. (St.Louis, Mo). Cadmium chloride was dissolved in saline solution $(0.9 \% \mathrm{NaCl})$. Melatonin was dissolved in ethanol before being diluted with saline. The final concentration of ethanol in the melatonin solution was $<1 \%$. All other chemicals were of highest quality available.

\section{Experimental Design} each:

The rats were randomly divided into 5 groups, 15 rats for

* The first group: was injected subcutaneously with cadmium chloride (Cd) at a dose of $5 \mathrm{mg} / \mathrm{kg}$ body weight for 22 days.

* The second group: was injected subcutaneously with melatonin $(10 \mathrm{mg} / \mathrm{kg} \mathrm{b.w})$ and Cd for 22 days. The administration of melatonin was $30 \mathrm{~min}$. before $\mathrm{Cd}$ injection and was given at 4 p.m. (two hours before light off).
* The third group: was injected subcutaneously with $\mathrm{Cd}$ ( $5 \mathrm{mg} / \mathrm{kg} \mathrm{b.w}$ ) for 22 days, and then left for recovery without any type of administration for another 22 days.

* The fourth group: was injected subcutaneously with $\mathrm{Cd}(5 \mathrm{mg} / \mathrm{kg} \mathrm{b.w})$ for 22 days, and then given daily subcutaneous injection of melatonin $(10 \mathrm{mg} / \mathrm{kg} \mathrm{b.w})$ for another 22 days.

* The fifth group: served as control and the rats were injected with vehicles only.

24 hours after the last injection, the rats were sacrificed by cervical dislocation.

\section{Tissue Preparations}

The specimens from the kidneys were rapidly excised, and cut conveniently into small pieces, which were used for morphological investigations. Another portion of the kidneys was frozen at $-40{ }^{\circ} \mathrm{C}$ for measurement of oxidative stress markers.

\section{Measurement Lipid Peroxidation (LPO)}

The method of measurement of oxidized lipids was based on that of Ohkawa et al. [33]. A 10 (w/v) tissue homogenate from kidney required for this assay (this homogenate contained $1 \% \mathrm{v} / \mathrm{v}$ dimethyl sulfoxide to prevent further oxidation). To $0.2 \mathrm{ml}$ Aliquots of tissue homogenate was added $0.2 \mathrm{ml} 8.1 \% \mathrm{w} / \mathrm{v}$ sodium dodecyl sulfate solution, $1.5 \mathrm{ml}$ $20 \% \mathrm{v} / \mathrm{v}$ acetic acid solution (PH 3.5) and $1.5 \mathrm{ml} 0.8 \% \mathrm{w} / \mathrm{v}$ thiobarbituric acid solution. The mixture was made up to 4.0 $\mathrm{ml}$ with distilled water and heated to $95{ }^{\circ} \mathrm{c}$ for $1 \mathrm{~h}$. The samples were cooled and centrifuged at $2000 \mathrm{xg}$ for $10 \mathrm{~min}$ and absorbance measured at $532 \mathrm{~nm}$. Results were expressed as n mol malondialdehyde formation per $\mathrm{g}$ tissue.

\section{Superoxide Dismutase (SOD) Activity}

SOD activity was determined at room temperature according to the method of Misra and Fridovich [34]. Ten microliters of tissue extract was added to $970 \mu \mathrm{l}(0.05 \mathrm{M}, \mathrm{pH}$ 10.2, $0.1 \mathrm{mM}$ EDETA) of sodium carbonate buffer. Twenty microliters of $30 \mathrm{mM}$ epinephrine (dissolved in $0.05 \%$ acetic acid) was added to the mixture to start the reaction. SOD activity was measured at $480 \mathrm{~nm}$ for $4 \mathrm{~min}$. Activity was expressed as the amount of enzyme that inhibits the oxidation of epinephrine by $50 \%$, which is equal to $1 \mathrm{U}$ per $\mathrm{mg}$ of protein. Protein concentrations were measured by the method of Bradford [35] using bovine albumin as standard.

\section{Measurement of Glutathione (GSH) Concentration}

GSH content was measured by a modification of the method of Beutler et al. [36]. Briefly, $500 \mu \mathrm{l}$ of tissue extract was added to $2.0 \mathrm{ml}$ of $0.2 \mathrm{M}$ phosphate buffer and $0.25 \mathrm{ml}$ $0.04 \%$ 5,5'dithio-bis 2-nitrobenzoic acid. Absorbance was read at $410 \mathrm{~nm}$. GSH content was expressed as nanomoles of GSH per mg of protein.

\section{Histological and Histopathological Examinations}

For the histological and histopathological examinations, pieces of the kidneys were fixed in $10 \%$ of neutral buffered formalin (PH 7.2), dehydrated in ascending series of ethanol, cleared in methyl benzoate and embedded in paraffin wax. Paraffin sections of 5 microns in thickness were prepared and stained with Harris's hematoxlin and eosin. 


\section{Electron Microscopy}

For electron microscopy, 5-10 small pieces $1 \times 1 \mathrm{~mm}$ in size were taken from the kidney of control and treated animals and fixed in 5\% cold glutaraldehyde immediately after dissecting the animal for 24-48 h. The specimens were then washed in phosphate buffer (PH 7.2) 3-4 times for 20 minutes each and post fixed in 1\% O4S4 for $2 \mathrm{~h}$, after that washed in the same puffer 4 times. Dehydration by ascending grades of alcohol (30, 50, 70, 90 and $100 \%$ for $2 \mathrm{~h}$ ) were done and embedded in epon araldite mixture. From the embedded blocks by LKB ultramicrotome semithin sections in thickness of $0.5 \mu$ were prepared for orientation the tissue and then ultrathin sections in thickness of 500-700 ${ }^{\circ} \mathrm{A}$ were made using Leica AG ultramicrotome and contrasted in uranyl acetate and lead citrate, as usual, examined by TEM $100 \mathrm{cxII}$ electron microscope and photographed [37].

\section{Quantitative Analysis of the Element}

The samples were dried by critical point dryner stiked in SEM holder and analyzed by using Oxford Link pentafet EDX model 6647 for detection of the elements and the percentage in relation to each other.

\section{Statistical Analysis}

The quantitative results were expressed as means $\pm \mathrm{SE}$. Differences between means were tested by the ANOVA followed by the Student-Newman-Keuls t-test. The percent of stimulation (S\%) or inhibition ( $\mathrm{I} \%$ ) was calculated.

\section{RESULTS}

Cadmium residue was increased in the kidney of $\mathrm{Cd}$ administered animals versus those of controls (Table 1). Melatonin administration decreased the element accumulation when it was given both $30 \mathrm{~min}$. before $\mathrm{Cd}$ and after $\mathrm{Cd}$ to the recovery group. As shown in Table 2, administration of cadmium significantly increased $(\mathrm{P}<0.01)$ LPO levels in the kidney homogenates versus those of control rats by $36.2 \%$. When melatonin was given (30 minutes before cadmium) to cadmium-administered rats, it significantly inhibited $(\mathrm{P}<0.01)$ the increase of LPO by $51.4 \%$. In the rats which left for recovery without any type of treatment for 22 days (Recov), the levels of the oxidized lipids were still increased $(4.1 \%)$ versus those of cadmium-administered animals. When melatonin was given for another 22 days for recovery $(\operatorname{Recov}+\mathrm{M})$, the levels of LPO were decreased $(35.8 \%)$ versus those of cadmium-administered rats. The comparison between the two recovery subgroups (Recv and Recov $+\mathrm{M})$ revealed that the levels of LPO was decreased $(38.3 \%)$ in the Recov $+\mathrm{M}$ group versus those of Recov one. Statistically, the use of melatonin in recovery (Recov $+M$ ) significantly $(\mathrm{P}<0.01)$ reduced the LPO levels.

The activity of SOD was inhibited $(\mathrm{P}<0.01)$ in the kidney homogenates of cadmium-administered animals versus those of controls (Table 3). The cadmium-induced inhibition of SOD activity was $56.8 \%$. The administration of melatonin to rats which given cadmium markedly stimulated $(\mathrm{P}<0.01)$ the activity of SOD by $42.3 \%$. In the animals, which left for recovery without any type of treatment for another 22 days (Recov), there was an increase in the activity of SOD $(13.2 \%)$ versus those of cadmium-administered animals. Administration of melatonin for another 22 days for recovery
$($ Recov $+M)$, increased the activity of SOD by $26.1 \%$ versus those of cadmium-administered rats $(\mathrm{P}<0.01)$. The comparison between Recv and Recov+M groups revealed that SOD activity was increased (11.4\%) in the Recov+M versus those of Recov one. Statistically, the increase of SOD activity induced by melatonin in recovery (Recov+M) was nonsignificant.

Table 1. Cadmium Content (Element) in the Kidney Tissue of Control and Different Treated Groups of Rats (EDX Attached to Scanning Electron Microscope [S.E.M])

\begin{tabular}{|c|c|c|c|}
\hline $\begin{array}{c}\text { Measurement/ } \\
\text { Groups }\end{array}$ & $\begin{array}{c}\text { Element } \\
\%\end{array}$ & $\begin{array}{c}\text { Atomic } \\
\%\end{array}$ & $\begin{array}{c}\text { Element Increase } \\
\text { or Decrease }\end{array}$ \\
\hline \hline Control & 0.0 & 0.0 & Increase $v s$ Control \\
\hline Cadmium & 2.18 & 0.55 & decrease $v s$ Cad. \\
\hline Cad+Melatonin & 1.24 & 0.32 & decrease $v s$ Cad. \\
\hline Recovery & 2.16 & 0.58 & $\begin{array}{c}\text { decrease } v s \text { Cad. } \\
\text { decrease } v s \text { Recov. }\end{array}$ \\
\hline Recov.+ Melatonin & 1.57 & 0.40 & \multicolumn{2}{|c}{} \\
\hline
\end{tabular}

Table 2. Mean Values \pm S.E of Lipid Peroxidation (MDA), Stimulation (\%) and Inhibition (\%) in Kidney Homogenates of Control and Different Treated Groups of Rats

\begin{tabular}{|c|c|c|c|}
\hline $\begin{array}{c}\text { Measurement/ } \\
\text { Groups }\end{array}$ & $\begin{array}{c}\text { LPO } \\
(\mathbf{n m o l} / \mathbf{g} \text { Tissue) }\end{array}$ & $\begin{array}{c}\text { Inhibition or } \\
\text { Stimulation \% }\end{array}$ & $\%$ \\
\hline \hline Control & $3.274 \pm 0.205^{\mathrm{a}}$ & & \\
\hline Cadmium & $4.460 \pm 0.301^{\mathrm{b}}$ & Stimulation $v s$ Control & 36.2 \\
\hline Cad+Melatonin & $2.166 \pm 0.201^{\mathrm{c}}$ & Inhibition $v s$ Cad. & 51.4 \\
\hline Recovery & $4.641 \pm 0.581^{\mathrm{b}}$ & Stimulation $v s$ Cad & 4.1 \\
\hline Recov.+ Melatonin & $2.865 \pm 0.154^{\mathrm{ac}}$ & $\begin{array}{c}\text { Inhibition } v s \text { Cad } \\
\text { Inhibition } v s \text { Recov. }\end{array}$ & 35.8 \\
\hline
\end{tabular}

Values in the same column with unlike superscript letters are significantly differing a $\mathrm{P}<0.05$.

Table 3. Mean Values \pm S.E of Superoxide Dismutase (SOD) Activity, Stimulation (\%) and Inhibition (\%) in Kidney Homogenates of Control and Different Treated Groups of Rats

\begin{tabular}{|c|c|c|c|}
\hline $\begin{array}{c}\text { Measurement/ } \\
\text { Groups }\end{array}$ & $\begin{array}{c}\text { SOD } \\
\text { (Units/mg Protein) }\end{array}$ & $\begin{array}{c}\text { Inhibition or } \\
\text { Stimulation \% }\end{array}$ & $\%$ \\
\hline \hline Control & $1.455 \pm 0.076^{\mathrm{a}}$ & & \\
\hline Cadmium & $0.629 \pm 0.025^{\mathrm{b}}$ & Inhibition $v s$ Control & 56.8 \\
\hline Cad+Melatonin & $0.895 \pm 0.023^{\mathrm{c}}$ & Stimulation $v s$ Cad. & 42.3 \\
\hline Recovery & $0.712 \pm 0.034^{\mathrm{bc}}$ & Stimulation $v s$ Cad & 13.2 \\
\hline Recov.+ Melatonin & $0.793 \pm 0.020^{\mathrm{c}}$ & $\begin{array}{c}\text { Stimulation } v s \text { Cad } \\
\text { Stimulation } v s \text { Recov. }\end{array}$ & $\begin{array}{c}26.1 \\
11.4\end{array}$ \\
\hline
\end{tabular}

Values in the same column with unlike superscript letters are significantly differing at $\mathrm{p}<0.05$.

Cadmium administration to the rats reduced total GSH concentrations $(\mathrm{P}<0.01)$ in the kidney compared to those of 
controls by $28.7 \%$ (Table 4 ). Melatonin administration to cadmium-administered rats markedly restored $(27.6 \%)$ the concentrations of GSH $(\mathrm{P}<0.01)$. In the rats, which left for recovery without any type of treatment for another 22 days (Recov), there was an increase in the concentration of GSH $(8.3 \%)$ versus those of cadmium-administered animals. In the rats which given melatonin for another 22 days for recovery $(\operatorname{Recov}+\mathrm{M})$, the concentration of GSH was increased $(23.5 \%)$ versus those of cadmium-administered rats $\mathrm{P}<0.01)$. The comparison between the two recovery groups (Recv and Recov $+\mathrm{M}$ ) revealed that GSH concentration was increased $(14 \%)$ in the Recov+M group versus those of Recov one.

Table 4. Mean Values $\pm \mathbf{S . E}$ of Glutathion (GSH) Concentration, Stimulation (\%) and Inhibition (\%) in Kidney Homogenates of Control and Different Treated Groups of Rats

\begin{tabular}{|c|c|c|c|}
\hline $\begin{array}{c}\text { Measurement } \\
\text { Groups }\end{array}$ & $\begin{array}{c}\text { GSH } \\
(\mathbf{n m o l} / \mathbf{m g} \text { Protein) }\end{array}$ & $\begin{array}{c}\text { Inhibition or } \\
\text { Stimulation \% }\end{array}$ & $\%$ \\
\hline \hline Control & $12.456 \pm 0.377^{\mathrm{a}}$ & & \\
\hline Cadmium & $8.882 \pm 0.255^{\mathrm{b}}$ & Inhibition $v s$ Control & 28.7 \\
\hline Cad+Melatonin & $11.329 \pm 0.459^{\mathrm{a}}$ & Stimulation $v s \mathrm{Cad}$. & 27.6 \\
\hline Recovery & $9.621 \pm 0.501^{\mathrm{bc}}$ & Stimulation $v s \mathrm{Cad}$ & 8.3 \\
\hline Recov.+ Melatonin & $10.971 \pm 0.373^{\mathrm{c}}$ & $\begin{array}{c}\text { Stimulation } v s \mathrm{Cad} \\
\text { Stimulation } v s \mathrm{Recov} .\end{array}$ & $\begin{array}{c}23.5 \\
14.0\end{array}$ \\
\hline
\end{tabular}

Values in the same column with unlike superscript letters are significantly differing at $\mathrm{p}<0.05$.

The histopathological examination of the kidneys of cadmium-treated rats (Fig. 2A-D) revealed major changes when compared with control rats (Fig. 1A-C). Such changes were; distinct spaces in-between the cortical tissue due to the cellular degeneration with appearance of inter tubular edema, dilation of Bowman's spaces and mesangial cell proliferation in the glomerulus (Fig. 2A). Also, hydropic degeneration and coagulative necrosis can be seen in Fig. (2B).

Electron microscopy showed hyper cellularity of the glomeruli that reflected numerous of mesangial cells with large nuclei and presence of numerous vacuoles in the cytoplasm (Fig. 2C). Necrobiosis of numerous tubular epithelial cells was observed and some of them slought and present in the lumen of the tubule (Fig. 2D).

Comparing with the cadmium-treated rats, melatonin treatment exerted some improvements; the cortical tubular portions retained their normality to a large extent (Fig. 3A). Nevertheless, some cellular degeneration was observed throughout the kidney tissue. In addition, few Malpighian corpuscles underwent some symptoms of injury. Electron microscopy of this group revealed more or less normal features of the glomeruli which appear like those of control animals (Fig. 3B). The tubular epithelial cells contain numerous electron-dense globules in the cytoplasm and normal mitochondria (Fig. 3C). Vacuole release was observed from some tubular epithelial cells to the lumen of the tubule.
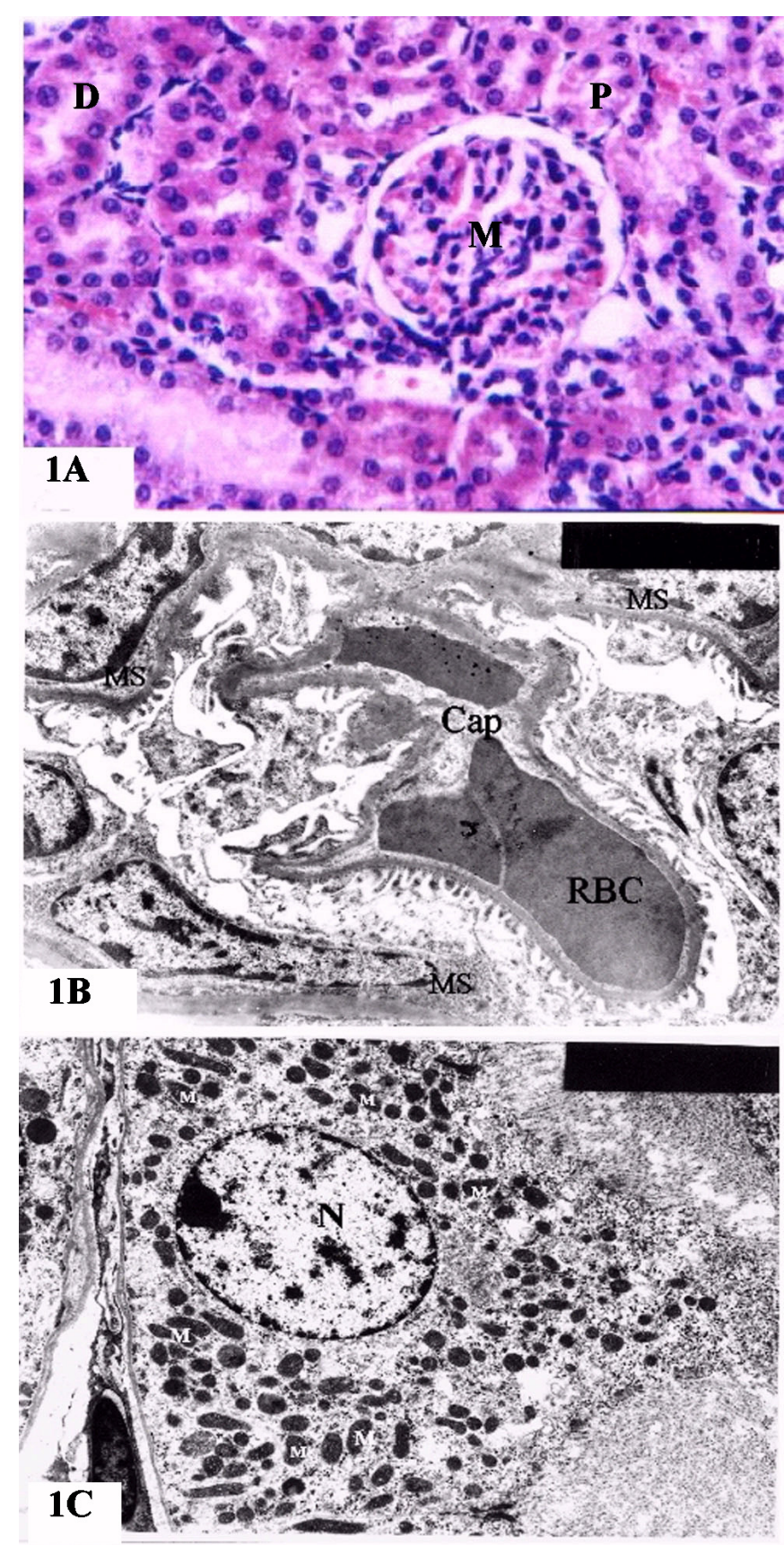

Fig. (1). (A) T.S of the kidney of control rat showing normal distal convoluted tubule (D) with cuboidal lining cells, Proximal convoluted tubule $(\mathrm{P})$ with pyramidal lining cells and Malpighian corpuscle (M). (H\&E, X 400). (B) Electron micrograph showing capillary tuft (Cap) with red blood corpuscles (RBC) and loose mesangial cells (MS). (X 5000). (C) Electron micrograph showing active cuboidal epithelial cell with vesicular nucleus $(\mathrm{N})$ numerous mitochondria (M). (X 4000).

Examination of the kidney sections obtained twenty two days progressive to the cadmium (Recov) still revealed marked histopathdogical lesions particularly in the cortical portions (Fig. 4A). As shown in these figures, the Malpighian corpuscles displayed some features of deformity. 


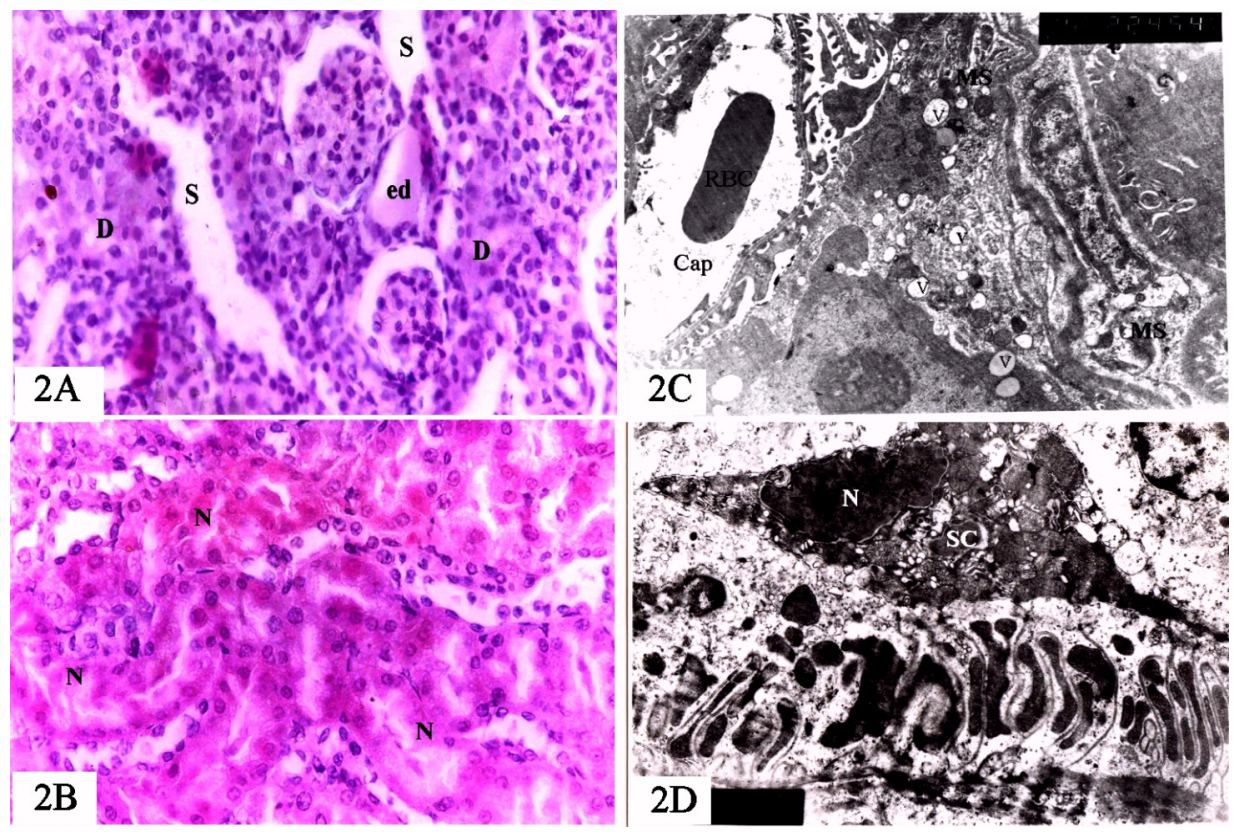

Fig. (2). (A) T.S of the kidney of cadmium-treated animal showing distinct spaces (S) in-between the cortical tissue, inter tubular edema (ed) and degeneration of the epithelial cells (D). (H\&E X 200). (B) T.S of the kidney of cadmium-treated animal showing hydrpic degeneration and coagulative necrosis (N). (H\&E X 400). (C) Electron micrograph showing the capillary tuft (Cap) with red blood corpuscles (RBC) and large mesangial cells (Ms) with vacuoles (V). (X 5000). (D) Electron micrograph showing a slought cell (urine cast) in the lumen of the tubule (SC) with condensed nucleus (N) and organelles. (X 5000).

The lining cells of some renal tubules underwent a noticeable degeneration. Moreover, inter-tubular hemorrhage and cellular necrosis were clearly observed. Electron micrograph examination revealed large amount of mesangial matrix with thickened basement membrane of the glomerular tuft (Fig. 4B). The tubular epithelial cells showed presence of somewhat normal mitochondria, high electron-dense globules seem to be fat and moderate electron-dense irregular in shape seem to be destructed absorbed red blood corpuscles (Fig. 4C). Microscopic examination of the kidney tissues of Recov $+\mathrm{M}$, showed a normal architecture of the renal tubules and glomeruli and appeared like those of controls. A noticeable regeneration of the lining cells of the proximal and distal convoluted tubules as well as the glomerular tufts also detected (Fig. 5A). Electron microscopy revealed less amount of mesangial matrix with slightly thickening of the basement membrane of the glomerular tuft compared to those of the recovery group (Fig. 5B). The renal tubular epithelial cells appear more or less similar to those of controls (Fig. 5C).

\section{DISCUSSION}

$\mathrm{Cd}$ accumulates unevenly in human tissues, and is concentrated primarily in lungs, liver, kidneys, brain, heart, and testes [38]. In the current study $\mathrm{Cd}$ administration to the rats leads to accumulation of the metal in the tissue of the kidneys versus control animals. Our results were matching the previous of Gerhardsson et al. [38]. A variety of mechanisms have been attributed to $\mathrm{Cd}$-induced toxicity. $\mathrm{Cd}$ interferes with the intracellular signaling network and gene regulation at multiple levels [39]. Melatonin administration to $\mathrm{Cd}-$ treated rats decreased the accumulation of the metal in the kidneys. Chwełatiuk et al. [40] described, in female mice, a decrease of tissue accumulation of Cd and MT synthesis, after melatonin was orally administered. In a recent article, Alonso-Gonzalez et al., [41] observed differences in $\mathrm{Cd}$ plasma concentration among animals receiving the same amounts of the metal, depending on whether they were cotreated with melatonin or the diluent. These effects could be attributed to the binding of melatonin to $\mathrm{Cd}$ by forming metal complexes [42] or by a melatonin-induced expression of metallothionein (MT) and the formation of Cd-MT complexes, the hypothesis considered by Alonso-Gonzalez et al. [43]. Melatonin significantly increased the Cd-induced expression of MT-2A in all cell types.

There is an increasing body of evidence that the toxicity of $\mathrm{Cd}$ may be associated with the production of reactive oxygen species (ROS) [44]. It has also been found that $\mathrm{Cd}$ induces oxidative stress in cultured human cells [45]. The mechanism by which $\mathrm{Cd}$ induces ROS formation is not yet known [18]. Previous studies have indicated that treatment of cells with $\mathrm{Cd}$ results in specific mitochondrial alterations [46]. Cd exposure also leads to mitochondrial dysfunction in the renal cortex of rats [47]. It has been reported that $\mathrm{Cd}$ induces alterations in activities of antioxidant enzymes such as SOD [48] and catalase [49]. Lipid peroxidation is also associated with Cd toxicity [49].

In the current study the results obtained regarding the concentrations of MDA (an indicator of lipid peroxidation), activitiy of SOD and GSH concentration in the kidney clearly indicate that $\mathrm{Cd}$ is able to induce the oxidative stress during repeated administration. There was an increase in the levels of oxidized lipids and decrease in both SOD activity and GSH concentration in the kidneys after Cd administration. Enhanced peroxidation of lipids in intra- and extracellu- 

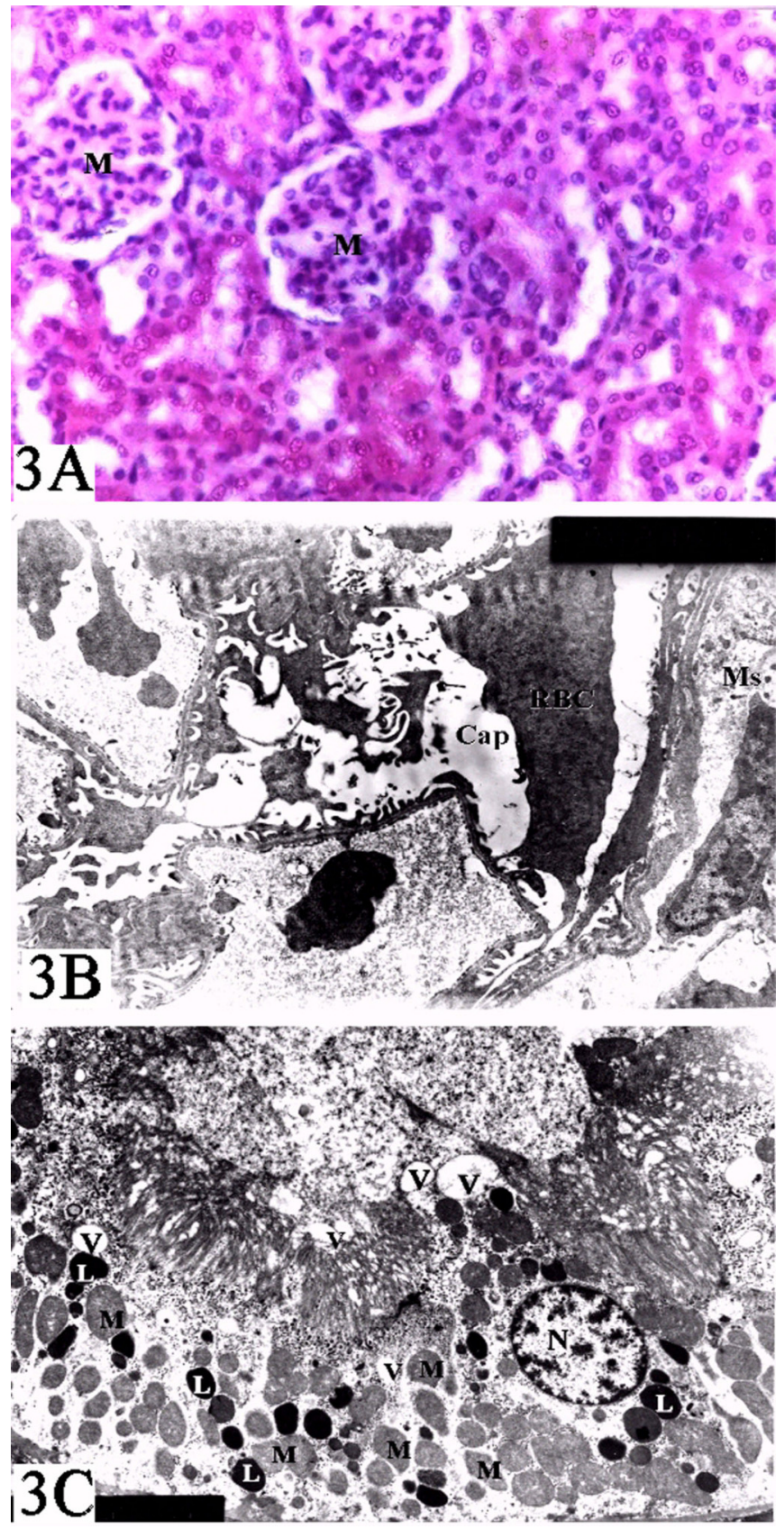

Fig. (3). (A) T.S of the kidney of rat treated with cadmium and melatonin revealing normal lining epithelial cells of the renal tubules (H\&E X 400). (B) Electron micrograph showing the capillary tuft (Cap) with red blood corpuscles (RBC) and normal mesangial cells (Ms). (X 4000). (C) Electron micrograph showing a tubular epithelial cell with normal mitocondria $(M)$, Nucleus $(N)$, fat globules (L) and released vacuoles (V). (X 2700).

lar membranes results in the damage to the cells, tissues and organs. SOD and GSH are important antioxidants that protect from this process via elimination of (ROS). When the cells are oxidatively challanged, GSH synthesis increases as a protective mechanism, but with the advancing dose of toxicant, the GSH synthesis is unable to compete with oxidative stress, and so the levels tend to decline [50]. SOD catalyzes the reaction of superoxide anion radical $\left(\mathrm{O}_{2}^{-{ }^{-}}\right)$dismutation to hydrogen peroxide $\left(\mathrm{H}_{2} \mathrm{O}_{2}\right)$ [51].

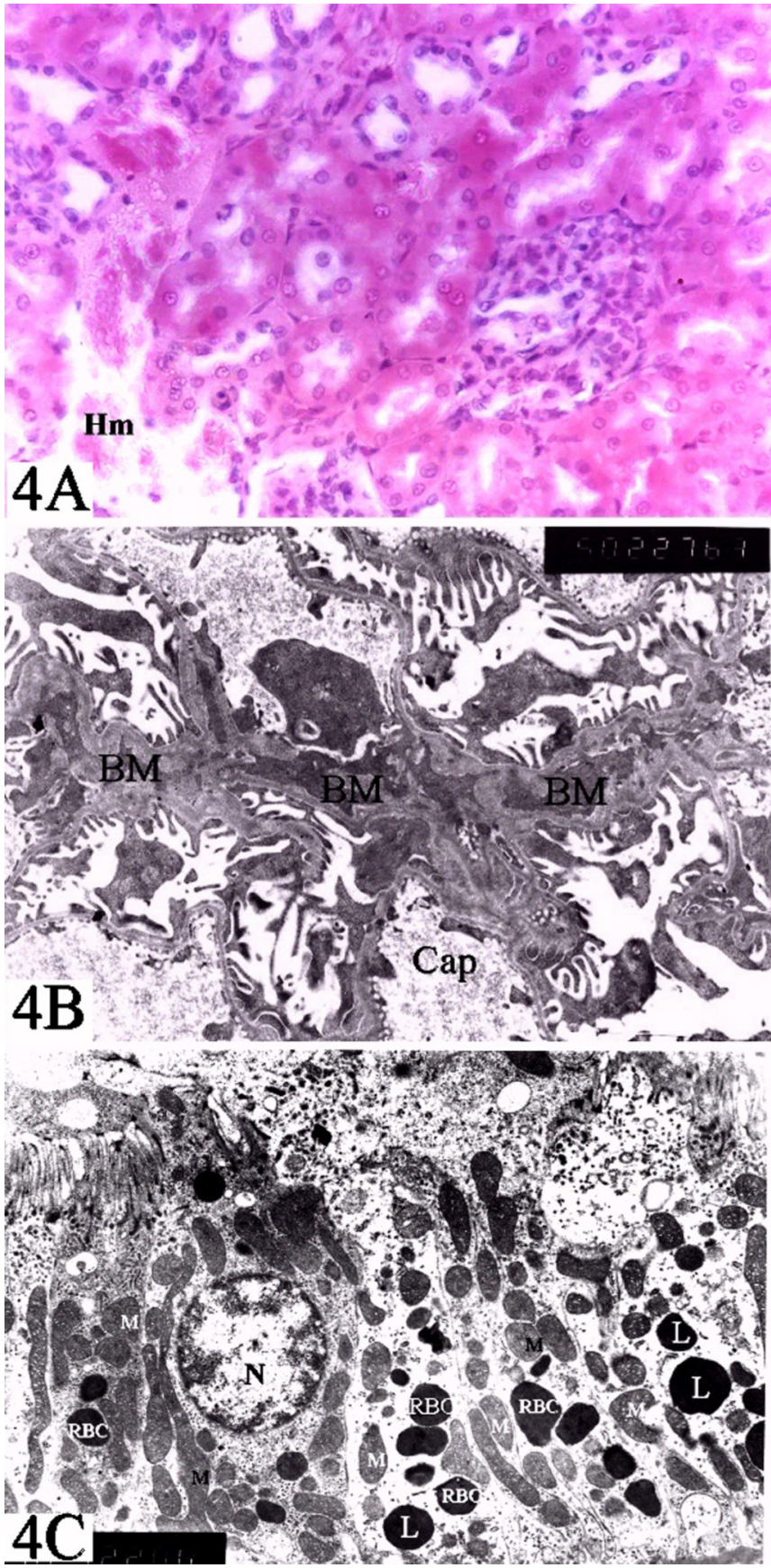

Fig. (4). (A) T.S of the kidney of rat of recovery subgroup showing intertubular hemorrhage $(\mathrm{Hm})$ while most cortical tubules appear normal in structure. (H\&E X 400). (B) Electron micrograph showing the capillary tuft (Cap) with red blood corpuscles and mesangial matrix with thick basement membrane (BM). (X 5000). (C) Electron micrograph showing a tubular epithelial cell with normal mitocondria $(\mathrm{M})$, Nucleus $(\mathrm{N})$, fat globules (L) and destructive red blood corpuscles (RBC). (X 4000).

The Cd-induced increase in MDA concentration in the kidney indicates an escalation of lipid peroxidation. The enhanced lipid peroxidation in the rats exposed to $\mathrm{Cd}$ might result from the reduction in the activities of antioxidant enzymes (SOD and CAT). The mechanism of Cd-induced lipid peroxidation is still not fully clarified. An available data indicate that the mechanism is multidirectional and may 

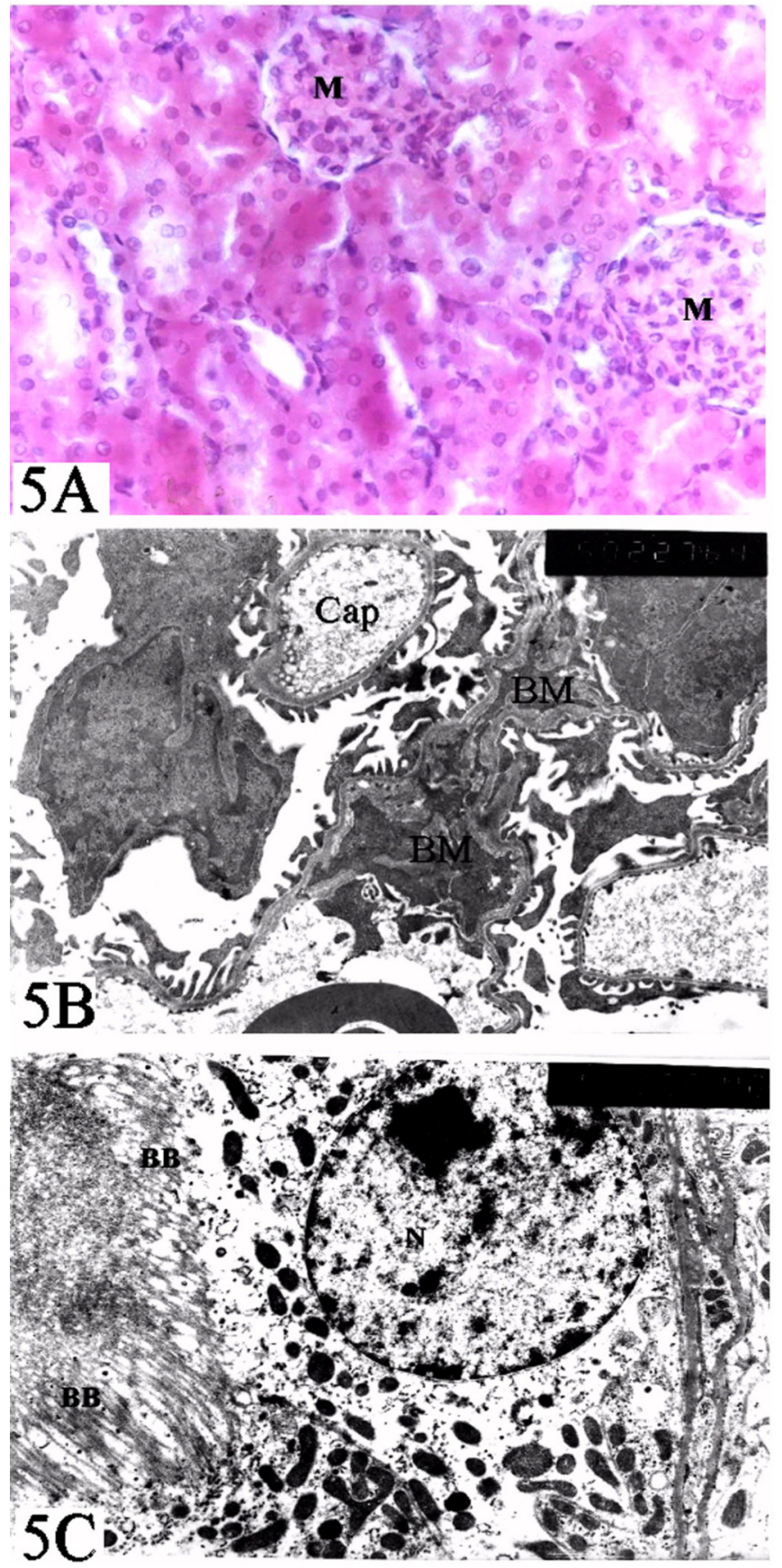

Fig. (5). (A) T.S of the kidney of rat of recovery plus melatonin revealing normal appearance of renal tubules and Malpighian corpuscles. (H\&E X 400). (B) Electron micrograph showing the capillary tuft (Cap) and mesangial matrix with slightly thick basement membrane (BM). (X 5000). (C) Electron micrograph showing a tubular epithelial cell with normal mitocondria, Nucleus $(\mathrm{N})$ and brush borders (BB). (X 2700).

involve a decrease in the level of glutathione and the total pool of sulphydryl groups and changes in the activities of antioxidant enzymes. These can induce the prooxidative state in the biological systems and, in turn, lead to peroxidation of polyunsaturated fatty acids [51-53].

In the current study melatonin administration to $\mathrm{Cd}$ treated or the recovery animals inhibited the increase of LPO and restored the decrease of both SOD activity and GSH concentration. It is remarkable that melatonin protection against the effects of $\mathrm{Cd}$ have been reported by different groups [22, 41, 54]. The well-demonstrated antioxidant properties of melatonin make it an efficient molecule for the protection of cell macromolecules from oxidative damage. For instance, melatonin reduces the damage induced by $\mathrm{KBrO}_{3}$ on the kidney [25]. Also, melatonin prevents the damage on DNA and the adverse effects on induced by 2 nitropropan [55] and diazinon [56].

The present study demonstrated the influence of $\mathrm{Cd}$ administration on the morphological changes of the kidney. Such changes included atypical tubules with hemorrhage in addition to cellular degeneration and necrosis. Also, many of ultrastructure alterations were detected in Cd-administered rats. The mechanisms of $\mathrm{Cd}$-induced renal damage result from the dissolution of the $\mathrm{Cd} /$ metallothionein complex in the kidney, exposing renal tissue to unbound cadmium. $\mathrm{Cd} /$ cell membrane binding, cellular apoptosis of renal proximal tubules, increased calcium loss in the urine, and increased protein excretion are seen in animals given longterm doses of cadmium or repeated doses of $\mathrm{Cd} /$ metallothionein complexes. Studies have also shown when the kidney is able to induce adequate de novo synthesis of metallothionein, no membrane damage occurs [57].

During the past decade several studies on the health effects of environmental exposure to Cd have shown that tubular effects occur at urinary cadmium concentrations of 1-2 $\mathrm{mg} / \mathrm{g}$ creatinine $[58,59]$. The tubular damage may be diagnosed in persons under environmental exposure at concentrations of urine $\mathrm{Cd}$ relatively lower than those in workers occupationally exposed to $\mathrm{Cd}$. It is plausible that the occupationally exposed group comprises a selection of relatively healthy people, whereas the general population also includes those more susceptible to the health effects of $\mathrm{Cd}$ activity [58]. This phenomenon, known as the healthy-worker effect, may be caused by medical selection and age. The results of several studies performed on populations that were environmentally exposed to $\mathrm{Cd}$ indicate that changes in sensitive renal biomarkers may occur at urinary cadmium levels lower than those found in adult male workers. Several markers of renal tubular dysfunction, including $\beta_{2}$-microglobuline $\left(\beta_{2} \mathrm{M}\right)$, retinol-binding protein (RBP), and $N$-acetyl- $\beta$-Dglucoseaminidase (NAG), were positively associated with urinary excretion of $\mathrm{Cd}$ [7]. Again, melatonin administration to $\mathrm{Cd}$-treated rats counteracts the toxic effect of $\mathrm{Cd}$ on the cortical tissue of the kidneys and the tissue appeared more or less normal. The protective effect of melatonin on the renal tubular tissue was studied against $\mathrm{KBrO}_{3}$ [25], schistosomiasis [60] and lead toxicity [27]. In addition, melatonin exerted potent protective effects against various nephrotoxic agents such as cisplatin [61], gentamicin [62], acetaminophen [63] and mercury(II) chloride [64].

In conclusion, exposure to $\mathrm{Cd}$ exerted oxidative damage, since the enzymatic activities involved in free radicals neutralization are depressed. Such events may be, at least in part, responsible for the morphological changes associated with $\mathrm{Cd}$ exposure. At the same time, melatonin protective action, which as we hypothesize, might be based on its powerful antioxidant properties is likely to be a valuable drug for protection against $\mathrm{Cd}$ toxicity. 


\section{REFERENCES}

[1] Agency, for Toxic Substances and Disease Registry (ATSDR) website, 2002. Available at: http://www.atsdr.cdc.gov/cxcx3.html.

[2] Trzcinka-Ochocka M, Jakubowski M, Razniewska G, Halatek T, Gazewski A.. The effects of environmental cadmium exposureon kidney function: the possible influence of age. Environ Res 2004; 95: 143-50.

[3] Van Assche FJ. A stepwise model to quantify the relative contribution of different environmental sources to human cadmium exposure, Paper to be presented at NiCad '98, Prague: Czech Republic 1998; pp. 21-2.

[4] Elinder CG, Lind B, Kjellstrom T, Linnman L, Friberg L. Cadmium in kidney cortex, liver, and pancreas from Swedish autopsies: estimation of biological half time in kidney cortex, considering calorie intake and smoking habits. Arch Environ Health 1976; 31: 292-302.

[5] IPCS, International programme on chemical safety. Environmental Health Criteria 134, Cadmium. WHO: Geneva 1992.

[6] Järup L, Berglund M, Elinder C, Nordberg G, Vahter, M. Health effects of cadmium exposure: a review of literature and a risk estimate. Scand J Work Environ Health 1998; 24 (Suppl): 1-52.

[7] Lauwerys R, Bernard AM, Roels HA, Buchet JP. Cadmium: exposure markers as predictors of nephrotoxic effects. Clin Chem 1994; 40: 1391-4.

[8] Staessen JA, Buchet JP, Ginucchio G, et al. Public health implications of environmental exposure to cadmium and lead: an overview of epidemiological studies in Belgium. J Cardiovasc Risk 1996; 3: 26- 41.

[9] Hellstrom L, Elinder CG, Dahlberg B, et al. Cadmium exposure and end-stage renal disease. Am J Kidney Dis 2001; 38: 1001-8.

[10] Satarug S, Baker JR, Urbenjapol S, et al. A global perspective on cadmium pollution and toxicity in nonoccupationally exposed population. Toxicol Lett 2003; 137: 65-83.

[11] Dudley RE, Gammal LM, Klaassen CD. Cadmium-induced hepatic and renal injury in chronically exposed rats likely role of hepatic cadmium-metallothionein in nephrotoxicity. Toxicol Appl Pharmacol 1985; 77: 414-26.

[12] Klaassen CD, Liu J. Role of metallothionein in cadmium-induced hepatotoxicity and nephrotoxicity. Drug Metab Rev 1997; 29: 79102.

[13] Zalups RK. Evidence for a basolateral uptake of cadmium in the kidneys of rats. Toxicol Appl Pharmacol 2000; 164: 15-23.

[14] Mates M. Effects of antioxidant enzymes in the molecular control of reactive oxygen species toxicology. Toxicology 2000; 153: 83104.

[15] Magder S. Reactive oxygen species: toxic molecules or spark of life? Crit Care 2006; 10(1): 208.

[16] Valko M, Izakovic M, Mazur M, Rhodes CJ, Telser J. Role of oxygen radicals in DNA damage and cancer incidence. Mol Cell Biochem 2004; 266: 37-56.

[17] Valko M, Rhodes CJ, Moncol J, Izakovic M, Mazur M. Free radicals, metals and antioxidants in oxidative stress-induced cancer. Chem Biol Interact 2006; 160: 1-40.

[18] Ercal N, Gurer-Orhan H, Aykin-Burns N. Toxic metals and oxidative stress. Part I. Mechanisms involved in metal-induced oxidative damage. Curr Top Med Chem 2001; 1: 529-39.

[19] Thevenod F. Nephrotoxicity and the proximal tubule insights from cadmium. Nephron Physiol 2003; 93(4): 87-93.

[20] Fowler BA. General subcellular effects of lead, mercury, cadmium, and arsenic. Environ Health Perspect 1978; 22: 37-41.

[21] Parmar P, Limson J, Nyokong T, Daya S. Melatonin protects against copper-mediated free radical damage. J Pineal Res 2002; 32: 237-42.

[22] Karbownik M, Gitto E, Lewinski A, Reiter RJ. Induction of lipid peroxidation in hamster organs by the carcinogen cadmium: melioration by melatonin. Cell Biol Toxicol 2001; 17: 33-40.

[23] Daniel S, Limson JL, Dairam A, Watkins GM, Daya S. Through metal binding, curcumin protects against lead- and cadmiuminduced lipid peroxidation in rat brain homogenates and against lead-induced tissue damage in rat brain. J Inorg Biochem 2004; 98 : 266-75.

[24] Abd-Elghaffar SKh, El-Sokkary GH, Sharkawy A. Aluminuminduced neurotoxicity and oxidative damage in rabbits: Protective effect of melatonin. Neuroendocrinol Lett 2005; 26(5): 609-16.
[25] El-Sakkary GH. Melatonin protects against oxidative stress induced by the kidney carcinogen KBro3. Neuroendocrinol Lett 2000; 21 : 461-8.

[26] El-Sokkary GH, Kamel ES, Reiter RJ. Prophylactic effect of melatonin in reducing lead-induced neurotoxicity in the rat. Cell $\mathrm{Mol}$ Biol Lett 2003; 8(2): 461-70.

[27] El-Sokkary GH, Abdel-Rahman GH, Kamel ES. Melatonin protects against lead-induced hepatic and renal toxicity in male rats. Toxicology 2005; 213 (1-2): 25-33.

[28] Marshall KA, Reiter RJ, Poeggeler B, Aroma OI, Halliwell B. Evaluation of the antioxidant activity of melatonin in vitro. Free Radic Biol Med 1996; 21: 307-15.

[29] Barlow-Walden LR, Reiter RJ, Abe M, et al. Melatonin stimulates brain glutathione peroxidase activity. Neurochem Int 1995; 26: 497-502.

[30] Reiter RJ. Oxidative processes and antioxidative defense mechanisms in the aging brain. FASEB J 1995; 9: 526-33.

[31] Ozturk G, Coskin S, Erbas D, Hasanoglu, E. The effect of melatonin on liver superoxide dismutase activity, serum nitrate and thyroid hormone levels. Jpn J Physiol 2000; 50: 149-53.

[32] Liu F, Ng TB. Effect of pineal indoles on activities of the antioxidant defense enzymes superoxide dismutase, catalase and glutathione reductase, and levels of reduced and oxidized glutathione in rat tissues. Biochem Cell Biol 2000; 78: 447-53.

[33] Ohkawa H, Ohishi N, Nagi K. Assay for lipid peroxides in animal tissues by thiobarbituric acid reaction. Anal Biochem 1979; 95: 351-8.

[34] Misra HP, Fridovich I. The role of superoxide anion in the autoxidation of epinephrine and a simple assay for superoxide dismutase. J Biol Chem 1972; 247: 3170-75.

[35] Bradford M. Rapid and sensitive method for quantification of protein utilizing the principle of protein-day binding. Anal Biochem 1976; 72: 248-54.

[36] Beutler E, Duron O, Kelly BM. Improved method for the determination of blood glutathione. J Lab Clin Med 1963; 61: 882-8.

[37] Bancroft JD, Stevens A. Theory and practice of histologic technique. $2^{\text {nd }}$ ed. Churchill Livingstone 1982; pp. 482-518.

[38] Gerhardsson L, Englyst V, Lundstrom NG, Sandberg S, Nordberg G. Cadmium, copper and zinc in tissues of deceased copper smelter workers. J Trace Elem Med Biol 2002; 16: 261-6.

[39] Beyersmann D, Hechtenberg S. Cadmium, gene regulation, and cellular signaling in mammalian cells. Toxicol Appl Pharmacol 1997; 144: 247-61.

[40] Chwelatiuk E, Wlostowski T, Krasowska A, Bonda E. The effect of orally administered melatonin on tissue accumulation and toxicity of cadmium in mice. J Trace Elem Med Biol 2006; 19: 259-65.

[41] Alonso-Gonzalez C, Gonzalez A, Mazarrasa O, et al. Melatonin prevents the estrogenic effects of sub-chronic administration of cadmium on mice mammary glands and uterus. J Pineal Res 2007; 42: 403-10.

[42] Limson J, Nyokong T, Daya S. The interaction of melatonin and its precursors with aluminium, cadmium, copper, iron, lead, and zinc: an adsorptive voltammetric study. J Pineal Res 1998; 24: 15-21.

[43] Alonso-Gonzalez C, Mediavilla D, Martinez-Campa C, et al. Melatonin modulates the cadmium-induced expression of MT-2 and MT-1 metallothioneins in three lines of human tumor cells (MCF7, MDA-MB-231 and HeLa). Toxicol Lett 2008; 181: 190-5.

[44] Szuster-Ciesielska A, Stachura A, Slotwinska M, et al. The inhibitory effect of zinc on cadmium-induced cell apoptosis and reactive oxygen species (ROS) production in cell cultures. Toxicology 2000; 145: 159-71.

[45] Bagchi D, Joshi SS, Bagchi M, et al. Cadmium- and chromiuminduced oxidative stress, DNA damage, and apoptotic cell death in cultured human chronic myelogenous leukemic K562 cells, promyelocytic leukemic HL-60 cells, and normal human peripheral blood mononuclear cells. J Biochem Mol Toxicol 2000; 14: 33-41.

[46] Wang Y, Fang J, Leonard SS, Rao KM. Cadmium inhibits the electron transfer chain and induces reactive oxygen species. Free Radic Biol Med 2004; 36: 1434-43.

[47] Tang W, Shaikh ZA. Renal cortical mitochondrial dysfunction upon cadmium metallothionein administration to Sprague-Dawley rats. J Toxicol Environ Health 2001; 62: 221-35.

[48] Hussain T, Shukla GS, Chandra SV. Effects of cadmium on superoxide dismutase and lipid peroxidation in liver and kidney of growing rats: in vivo and in vitro studies. Pharmacol Toxicol 1987; 60: 355-8. 
[49] Shaikh ZA, Vu TT, Zaman K. Oxidative stress as a mechanism of chronic cadmium-induced hepatotoxicity and renal toxicity and protection by antioxidants. Toxicol Appl Pharmcol 1999; 154: 25663.

[50] Pathak N, Khandelwal S. Oxidative stress and apoptotic changes in murine splenocytes exposed to cadmium. Toxicology 2006; 220(1): 26-36.

[51] Stohs SJ, Bagchi D. Oxidative mechanisms in the toxicity of metal ions. Free Radic Biol Med. 1995; 18: 321-36.

[52] Bagchi D, Bagchi M, Hassoun EA, et al. Cadmium induced excretion of urinary lipid metabolites, DNA damage, glutathione depletion, and hepatic lipid peroxidation in Sprague Dawley rats. Biol Trace Elem Res 1996; 53: 143-47.

[53] Bagchi D, Bagchi M, Hassoun EA, Stohs SJ. Molecular inhibitory mechanisms of antioxidant enzymes in rat liver and kidney by cadmium. Toxicology 2002; 179: 37-50.

[54] Eybl V, Kotyzova D, Koutensky J. Comparative study of natural antioxidants- curcumin, resveratrol and melatonin-in cadmiuminduced oxidative damage in mice. Toxicology 2006; 225 : 150-56.

[55] EL-Sokkary GH. Inhibition of 2-nitropropane induced cellular proliferation, DNA synthesis and histopathological changes by melatonin. Neuroendocrinol Lett 2002; 23: 335-40.

[56] Sarabia L, Maurer I, Bustos-Obrego'n E. Melatonin prevents damage elicited by the organophosphorous pesticide diazinon on mouse sperm DNA. Ecotoxicol Environ Saf 2009; 72: 663-8.
[57] Klaassen CD, Liu J, Choudhuri S. Metallothionein: an intracellular protein to protect against cadmium toxicity. Annu Rev Pharmacol Toxicol 1999; 39: 267-94

[58] Järup L, Hellstrom T, Alfven T, et al. Lowlevel exposure to cadmium and early kidney damage; the OSCAR study. Occup Environ Med 2000; 57: 668-72.

[59] Noonan CW, Sarasua SM, Campagna D, Kathman S, Lybarger JA, Mueller P. Effects of exposure to low levels of environmental cadmium on renal biomarkers. Environ Health Perspect 2002; 110 (2): 151-5.

[60] El-Sokkary GH, Omar HM, Hassanein AM, Cuzzocrea S, Reiter RJ. Melatonin reduces oxidative damage and increases survival of mice infected with Schistosoma mansoni. Free Radic Biol Med 2002; 32(4): 319-32.

[61] Sener G, Satiroglu H, Kabasakal L, et al. The protective effect of melatonin on cisplatin nephrotoxicity. Fundam Clin Pharmacol. 2000; 14(6): 553-60.

[62] Sener G, Sehirli AO, Altunbas HZ, et al. Melatonin protects against gentamicin-induced nephrotoxicity in rats. J Pineal Res 2002; 32(4): 231-36.

[63] Sener G, Sehirli AO, Ayanoğlu-Dülger G. Protective effects of melatonin, vitamin $\mathrm{E}$ and $\mathrm{N}$-acetylcysteine against acetaminophen toxicity in mice: a comparative study. J Pineal Res 2003; 35(1): 618 .

[64] Sener G, Sehirli AO, Ayanoglu-Dülger G. Melatonin protects against mercury(II)-induced oxidative tissue damage in rats. Pharmacol Toxicol 2003; 93(6): 290-6.

(C) El-Sokkary et al.; Licensee Bentham Open.

This is an open access article licensed under the terms of the Creative Commons Attribution Non-Commercial License (http://creativecommons.org/licenses/by$\mathrm{nc} / 3.0 /$ ) which permits unrestricted, non-commercial use, distribution and reproduction in any medium, provided the work is properly cited. 